\title{
Amplification of Brugia malayi DNA using Hha1 Primer as a Tool
}

\author{
Mohd. Saeed ${ }^{1,2}$, S. Siddiqui ${ }^{2}$, Preeti Bajpai ${ }^{2}$, A. K.Srivastava ${ }^{1}$ and Huma Mustafa ${ }^{3, *}$ \\ ${ }^{1}$ College of Applied Medical Sciences, Department of Clinical Lab. Sciences, University of Hail, Hail, KSA \\ ${ }^{2}$ Department of Bioscience, Integral University, Lucknow, India \\ ${ }^{3}$ Council of Science and Technology, Uttar Pradesh, India
}

\begin{abstract}
Lymphatic filariasis, a neglected parasitic disease caused by tissue dwelling human filarial nematodes such as Wuchereria bancrofti, Brugia malayi and B. timori is considered to be a major complication for the socio-economic development in developing countries. A number of inflammatory responses are associated with the diseases such as adeno-lymphangitis, lymphoedema, hydrocele and elephantiasis. The present study is directed towards the identification and amplification of Hha 1 gene for diagnosis of B. malayi. The specific primer Hha1 specific to Brugia malayi was used for detecting the parasites and was found to give optimum yield in the positive control samples. The results were confirmed from the amplified fragment having size of $322 \mathrm{bp}$ of B. malayi. Using this primer as a diagnostic tool for the detection of filariasis might be the most promising aspect of the study and offers scope for detection of both the parasites even at low levels of infection.
\end{abstract}

Keywords: Polymerase chain reaction, Diagnotic, Brugia malayi.

\section{INTRODUCTION}

Filariasis has been an issue of concern especially in tropical and sub tropical countries infecting approximately 120 million people. With tools currently available, filariasis in principle could be eliminated but the time period can extend up to 20 years [1,2]. Diagnosis plays a significant role in the management of disease, both at the level of patient and at the level of disease control authorities in populations. The most widely accepted method for the diagnosis of filarial infection is microscopic examination of blood for microfilaria (mf) which has limited sensitivity and is not feasible for large-scale screening of human populations in endemic areas. In epidemiological surveys, the alternate technique used to detect and characterize filarial parasites in vectors includes the collection, dissection and microscopy, this technique is not reliable because the mosquitoes may carry both human and animal filarial parasites, which cannot be distinguished biochemically or morphologically $[3,4]$. Currently, there is no fast, reliable and sensitive biochemical or immunological method for distinguishing closely related species or sub-species of filarial parasites. In order to overcome some of these shortcomings, improved methods for the diagnosis of filarial infections are needed to study the transmission, epidemiology and facilitate surveillance activities to monitor control efforts [5].

In recent years, sincere efforts have been focused on the development of specific diagnostic methods based on

*Address correspondence to this author at the Council of Science and Technology, Uttar Pradesh, India; Tel: +919453895703;

E-mail: humamustafa1@yahoo.co.in deoxyribonucleic acid (DNA) probes to replace the conventional method for diagnosis of disease [6,7]. These tests encountered some problems as mosquitoes contain PCR inhibitor $[8,9]$ due to which DNA undergoes degradation during collection, transport and storage [10] although the PCR assay was found to be specific but sensitivity was considerably low in samples with low microfilarial counts $(<8 \mathrm{mf} / \mathrm{ml})$ [11].

Therefore, the present study was directed towards the characterization of repeated DNA sequences of $B$. malayi. These sequences could be used for making very sensitive DNA hybridization assay/ PCR primers to detect filarial parasites.

\section{MATERIALS AND METHODS}

\section{Isolation of Microfilaria}

Brugia malayi adult female parasites were isolated from the lungs and heart of experimentally maintained 6-8 week old infected Mastomys coucha. The female parasites were microscopically dissected to recover the microfilaria from the ovary. The microfilariae were washed by sterile $100 \mathrm{mM}$ PBS and stored at $-20^{\circ} \mathrm{C}$ until used [12].

\section{Isolation of Genomic DNA}

The genomic DNA of $B$. malayi, microfilarae was isolated using commercially available genomic DNA isolation kits (Bangalore Genei). Briefly, the microfilaria were put in a final volume of $1.85 \mathrm{ml}$ in cell suspension solution and were lysed using blender buffer $(0.1 \mathrm{M} \mathrm{NaCl}$, $0.2 \mathrm{M}$ Sucrose, $0.1 \mathrm{M}$ Tris-HCl, $0.05 \mathrm{M}$ EDTA, 0.5\% SDS, 


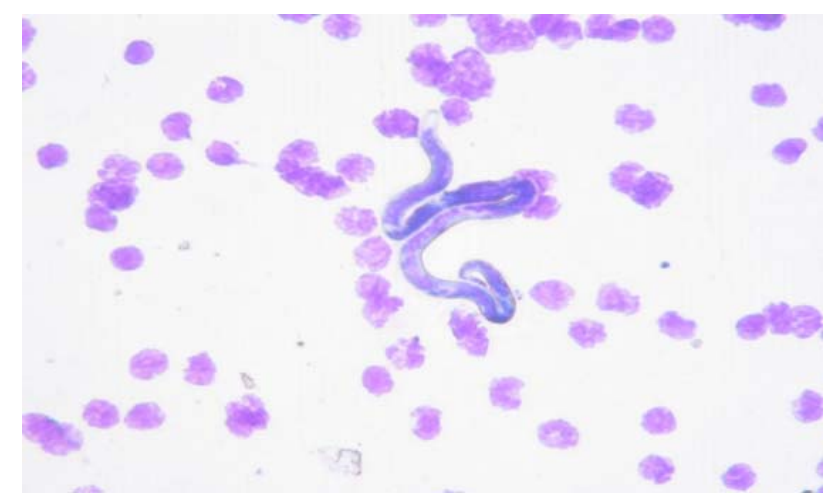

Fig. (1). Microscopic observation of mf of Burgiya malayi.

at pH 9.1 in sterile distilled water) using a sonicator. Then 10 $\mu \mathrm{l}$ RNase was mixed to $100 \mu \mathrm{l}$ of cell lysis and was incubated at $50^{\circ} \mathrm{C}$ for $15 \mathrm{~min}$. Later, $25 \mu \mathrm{l}$ of Proteinase $\mathrm{K}$ was mixed thoroughly and incubated at $55^{\circ} \mathrm{C}$ for $30 \mathrm{~min}$. Then lysate was loaded on the DNeasy membrane and centrifuged to remove the contaminants. The membrane was washed twice to remove all the remaining contaminant and enzyme inhibitors and the DNA was eluted in the elution buffer. The eluted DNA was mixed with $2 \mathrm{X}$ volume of absolute alcohol and $0.25 \mathrm{X}$ of $8 \mathrm{M}$ potassium acetate and incubated overnight at $4^{\circ} \mathrm{C}$ and the centrifuged at $15000 \mathrm{rpm}$ for $15 \mathrm{~min}$. The DNA pellet was washed with $70 \%$ alcohol and air dried. The pellet was suspended in $20 \mu \mathrm{l}$ of distilled water. All the DNA samples were kept at $-20^{\circ} \mathrm{C}$ until used.

The isolated filarial DNA was estimated spectrophotometrically at $280 \mathrm{~nm}$ for the quantity of DNA content. Both the isolated DNA was electrophorised using a horizontal electrophoretic unit. Briefly, $10 \mu \mathrm{l}$ of DNA was analyzed by electrophoresis on a $1 \%$ agarose gel with $1 \mathrm{X}$ $\mathrm{TBE}$ as the running buffer. A $1000 \mathrm{bp}$ ladder molecular weight marker was included on each. Gels were stained with ethidium bromide and visualized under UV light at $265 \mathrm{~nm}$ in a transilluminator.

\section{PCR}

The primers were designed for filarial adult parasite specific DNA based on sequence from DNA databank, EST (Gene Runner), highly repeated sequence of filarial DNA and homologous sequence in the genome of $B$. malayi. These primers were purchased commercially (Imperial Life Science). The forward and reverse primer sequences for $B$. malayi were (Hha1 F 5'-GCG CAT AAA TTC ATC AGC3', Hhal R 5'-GCG CAA AAC TTA ATT ACA AAA GC3') respectively. The PCR kit (Fermentas Pvt. Ltd) was used and the temperature conditions for thermal cycler (Bio Rad) were of 35 cycles at $94^{\circ} \mathrm{C}$ for $5 \mathrm{~min}$ followed by $94^{\circ} \mathrm{C}$ for 1 min, then $59.6^{\circ} \mathrm{C}$ for $1 \mathrm{~min}$ and $72^{\circ} \mathrm{C}$ for $1 \mathrm{~min}$ and finally $72^{\circ} \mathrm{C}$ for $10 \mathrm{~min}$. The above designed primers were used for amplification of the microfilarial DNA from $B$. malayi. The amplicon of $322 \mathrm{bp}$ of $B$. malayi was obtained. The molecular weight was determined in agarose gel $(1.5 \%)$ electrophoresis.

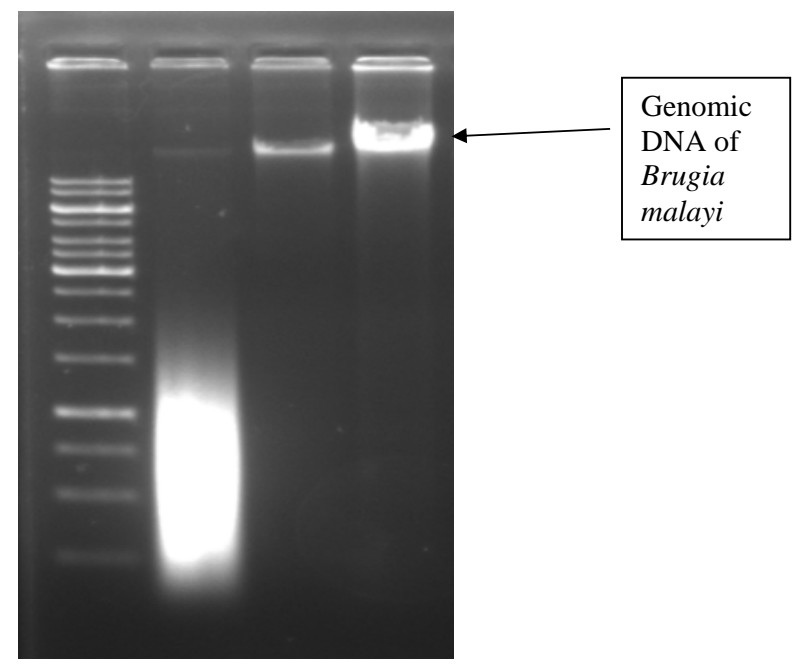

Fig. (2). Genomic DNA of mf of Brugia malayi Ladder ranging from $1000 \mathrm{bp}$ to $250 \mathrm{bp}$.

\section{RESULTS AND DISCUSSION}

The most widely accepted diagnostic tool for filarial infections is microscopic examination of microfilariae. This approach has limited sensitivity and feasible for diseaseendemic areas, where large scale screening has to be done and expert is unable to distinguish among the different filarial parasitic species due to their similar morphology. Moreover, it is a tedious method and inconvenient for both the patients as well as the collector as the blood samples are collected between 00:00 to 2:00 a.m.

With the emergence of DNA based technologies, molecular methods have already been reported for Brugia malayi [13]. The sensitivity and specificity of this assay have demonstrated its potentiality to be used as an efficient tool for the diagnosis of filariasis in blood samples. To proceed in this direction, the present study was accordingly planned. The results reveal the typical morphology of the $B$. malayi microfilariae as shown in Fig. (1). The parasitic isolated DNA was tested and amplified using the primer (Hha1), specific to $B$. malayi in a thermal cycler (BioRad, USA) (Fig. 2). The specific primer used for detecting the parasites was found to give optimum yield in the positive control samples. This was confirmed from the amplified fragment size of 322 bp for B. malayi (Fig. 3). The recognition site for Hha1 in $B$. malayi repeats contains the Alu I and $R s a$ I recognition sites. The agarose gel electrophoresis was done to check the molecular weight of amplicons. Thus, it can be concluded that the HhaI primer can be used to detect the $B$. malayi DNA specifically in the patient samples.

Prevalence of the neglected disease can be estimated from the infection status of the mosquitoes and the human population in an area. Apart from the factors like specificity and sensitivity, cost effectiveness is the essential component of any technique that is employed for diagnosis. The results indicate that this method takes care of the cost factor by diagnosing either parasite in a single step PCR. The most positive application it offers is to screen the status of 


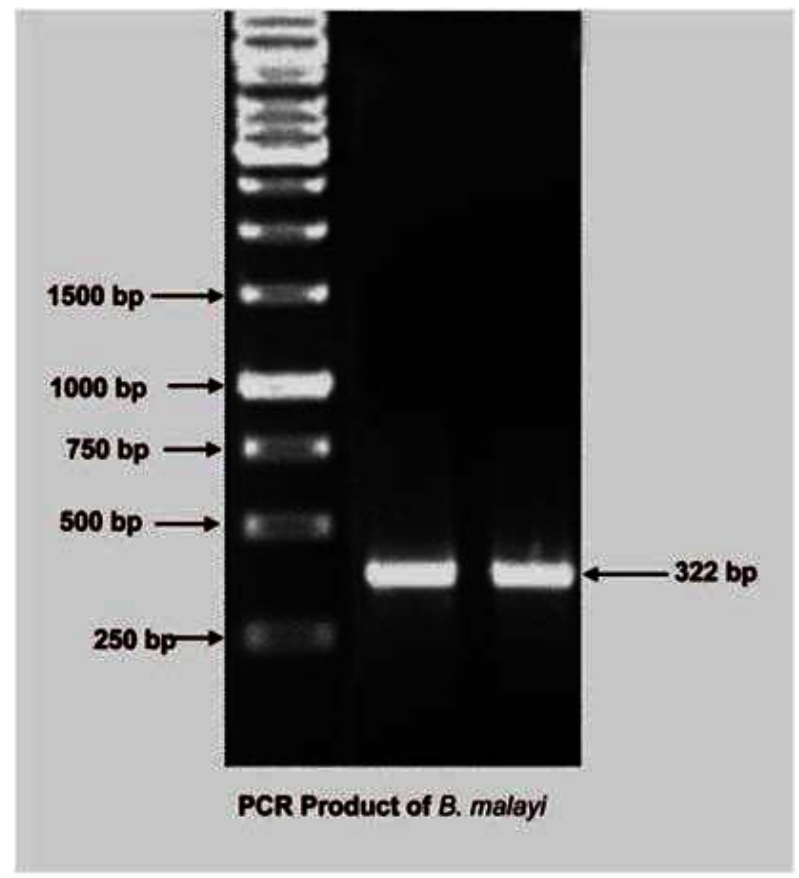

Fig. (3). PCR amplified product of Hhal gene Brugia Malayi.

endemicity in an area by handling large number of blood samples in relatively short time and at low cost. The multiple applicability of this method proves its effectiveness to be used as a diagnostic tool for the determination of filariasis.

\section{CONCLUSION}

In this study, we are reporting a primer Hhal specific to Brugia malayi that could be used as a diagnostic tool for the detection of lymphatic filariasis. This study offers scope for the detection of filarial parasites even at low levels of infection.

\section{CONFLICT OF INTEREST}

The authors confirm that this article content has no conflict of interest.

\section{ACKNOWLEDGEMENTS}

We would like to express our sincere thanks to Vice Chancellor, Integral University, Lucknow, India for providing necessary facilities and encouragement. One of the author's (MS) is thankful to UGC, New Delhi for granting Maulana Azad National Fellowship.

\section{REFERENCES}

[1] Katiyar D, Singh LK. Filariasis: current status, treatment and recent advances in drug development. Curr Med Chem 2011; 14(18): 2174-85.

[2] Goodman DS, Orelus JN, Roberts JM, Lammie PJ, Strit TG. PCR and mosquito dissection as tools to monitor filarial infection levels following mass treatment. Filaria 2003; $2: 11$.

[3] Nuchprayoon, S. DNA-based diagnosis of lymphatic filariasis Southeast Asian J Trop Med Public Health 2009; 40(5): 904-913.

[4] Sim BKL, Mak JW, Cheong WH, et al. Identification of Brugia malayi vectors with a species-specific DNA probe. Am J Trop Med Hyg 1986a; 35: 559-64.

[5] Sim BKL, Piessens WF, Wirth DF. A DNA probe cloned in Escherichia coli for the identification of Brugia malayi. Mol Biochem Parasitiol 1986b; 19: 117-23.

[6] Chandrashekar R, Curtis KC, Ramzy RM, Liftis F, Li B, Weil GJ. Improvement and Application of a Polymerase Chain Reaction System for Detection of Wuchereria bancrofti in Culex quinque fasciatus and Human Blood Samples. Molecular cloning of Brugia malayi antigen for diagnosis of lymphatic filariasis. Mol Biochem Parasitol 1994; 64: 261-71.

[7] Arora K, Chand S, Malhotra BD. Recent developments in biomolecular electronics techniques for food pathogens. Anal Chim Acta 2006; 568(1): 259-74.

[8] Siridewa K, Karunanayake EH, Chandrasekharan NV, et al. Cloning and characterization of a repetitive DNA sequence specific for Wuchereria bancrofti. Am J Trop Med Hyg 1994; 51: 495-500.

[9] Hunt, PW. Molecular diagnosis of infections and resistance in veterinary and human parasites. Veterinary Parasitol 2011; 180(1): $12-46$

[10] Dissanayake S, Piessens WF. Detection of amplified Wuchereria bancrofti DNA in mosquitoes with a non-radioactive probe. Mol Biochem Parasitol 1991; 45: 49-56.

[11] Cooper RD. Preservation of anopheline mosquitoes for DNA probe analysis. J Mos Con Ass 1998; 14: 58-60.

[12] Farid HA, Hammad RE, Hassan MM, et al. Detection of Wuchereria bancrofti in mosquitoes by the polymerase chain reaction: a potentially useful tool for large scale control programmes. Trans R Soc Trop Med Hyg 2001; 95: 29-32.

[13] Singh DP, Rathore S, Misra S, Chatterjee RK, Ghatak SN, Sen AB. Studies on causation of adverse reactions in microfilaraemic host following diethylcarbamazine therapy (Dipetalonema viteae in Mastomys natalensis). Trop Med Parasitol 1985; 36 (1): 21-24.

(C) Saeed et al.; Licensee Bentham Open.

This is an open access article licensed under the terms of the Creative Commons Attribution Non-Commercial License (http://creativecommons.org/licenses/by$\mathrm{nc} / 3.0 /$ ), which permits unrestricted, non-commercial use, distribution and reproduction in any medium, provided the work is properly cited 